\title{
EDUCATION POLICY AND MOBILITY: SOME BASIC RESULTS
}

\author{
ULRICH HANGE \\ CESIFo WORKING PAPER NO. 937 \\ CATEGORY 1: PUBLIC FINANCE \\ MAY 2003
}

An electronic version of the paper may be downloaded

- from the SSRN website: $\quad$ www.SSRN.com

- from the CESifo website: www.CESifo.de 


\title{
EDUCATION POLICY AND MOBILITY: SOME BASIC RESULTS
}

\begin{abstract}
This paper analyzes regional public education policy in the presence of mobile workers. Labor market integration leads to fiscal competition, shifting the whole burden of taxation to immobile workers. In the case of mobile skilled workers, this results in income inequalities and inefficient low investment in human capital. This is even more pronounced if politicians are partly self-interested. In contrast, if unskilled workers are mobile, all households receive the same net earnings. In this scenario, a benevolent government ensures an efficient level of human capital investment, while partly selfish politicians choose to invest too little in education.
\end{abstract}

JEL Code: H21, H23.

Keywords: education policy, factor mobility.

Ulrich Hange

CESifo (University of Munich \& Ifo Institute)

Schackstrasse 4

80539 Munich

Germany

ulrich.hange@ces.vwl.uni-muenchen.de 


\section{Introduction}

Education ranks high on the political as well as the economic research agenda. Education as investment in human skills and capital may help to foster economic growth, enhance productivity, affect personal and social development, and explain income and wealth distribution. Especially, in countries that are not endowed with large reserves of natural resources human capital is the major source of national wealth and thus of special public concern. Many countries invest a substantial share of national resources in education, mostly funded by the government. ${ }^{1}$ The reasons for this strong public engagement in education are manifold, although human capital is mainly seen as a private good. ${ }^{2}$

At the same time, we observe a tendency towards regional and economic integration during the last decades. The most prominent example is the European Union, granting free migration of goods, services, capital and labor within its member states. Enhancing mobility of goods and factors, integration is expected to improve the allocation of resources. However, this also means increasing mobility of tax bases that may increase the cost to governments of raising revenue, altering distributive and allocative consequences of public policies. ${ }^{3}$

In this paper we present some basic insights with regard to public education policy when workers are perfectly mobile. Building on the inspiring work by Wildasin (2000b) we extend his model in several respects. First, we analyze not only the case of mobile skilled workers, but also the scenario of mobile unskilled workers, which is more feared by the public and politicians. ${ }^{4}$ Second, while Wildasin (2000b) investigates the optimal policy of a benevolent government, his analysis neglects the fact

\footnotetext{
${ }^{1}$ In 1998, all OECD countries as a whole spent 5.7 percent of GDP on educational institutions. On average across these countries, 89 percent of all funds for educational institutions come from public sources. C.f. OECD (2001).

${ }^{2}$ For a comprehensive and intuitive overview from an economic perspective c.f. Stiglitz (2000). In this paper we do not stress this issue further but take as given that education is provided and financed by the government.

${ }^{3}$ For a comprehensive overview of this issue c.f. Wellisch (2000) and Wildasin (2000a).

${ }^{4}$ While empirically the propensity to migrate rises with education, c.f. Greenwood (1997), international migration towards the European Union is mainly a phenomenon of unskilled labor driven by huge income differences and decreasing migration costs, c.f. Sinn (2002) and Wellisch (2002).
} 
that some bureaucrats in each governments administration have strong incentives to use some public revenue for their own purposes. According to Niskanen (1971), this Leviathan-type government seeks to maximize its budget. These sharply different views of government's behavior reflect equally different perceptions of government policy-making. While the first optimistically assumes that governments are benevolent utility maximizers of their citizens, the Leviathan government is supposed to be wholly self-interested. Following the studies of Edwards and Keen (1996) and Hange and Wellisch (1998) we try to reconcile both views by assuming that governments are neither entirely benevolent nor fully selfish and compare the outcome to the benevolent governments policy. ${ }^{5}$

Beside the well-known result that governments competing for mobile factors will abstain from taxing them, this study presents a number of further basic insights on optimal education policy in the presence of mobile households. First, if skilled workers are mobile they will be better off than unskilled households, because immobile unskilled workers have to bear all education costs. Thus, government restricts the access to the public education system. Second, if the government is inequality averse and skilled households are mobile, public education is inefficiently low. This is even more pronounced when governments are partly selfish.

In contrast, if unskilled workers are mobile all households are equally well off. But, while a benevolent government ensures an efficient level of education, partly self-interested politicians invest too little in human capital. The reason for this is, that partly-selfish government would like to make skilled workers worse off than mobile unskilled households. But this is impossible because no one can be forced to acquire skill if she will be worse off. Hence, in order to capture some revenue for its own purposes, government's policy has to guarantee that gross income of skilled workers must exceed that of unskilled households by more than only the costs of skill acquisition.

To derive these insights the paper is organized as follows. In section 2 we develop

\footnotetext{
${ }^{5}$ Andersson and Konrad (2001, 2002) analyze the optimal education policy of Leviathan-type and benevolent governments facing a time consistency problem. One of their findings is that the benevolent government may support private skill acquisition, while the Leviathan government tries to prevent households from mobility-enhancing education investment.
} 
the basic model in line of Wildasin (2000b) and analyze as a benchmark case the optimal education policy in a closed economy. Section 3 presents the optimal government's behavior when skilled workers are perfectly mobile, whereas in section 4 we investigate the case when unskilled labor is perfectly mobile. Finally, section 5 summarizes and gives some concluding remarks.

\section{Education Policy in a Closed Economy}

Consider an economy consisting of many identical jurisdictions or regions. Each is populated by $N$ initially identical native households. A household has to decide whether to acquire additional education and become a skilled worker or to remain unskilled. After the educational decision is met and education has been completed, all households are endowed with one unit of labor which is inelastically supplied to firms. A skilled worker earns the gross wage $w_{h}$ while an unskilled worker receives the gross return $w_{l} .{ }^{6}$ The costs of education are constant and sum up to $e$ for each skilled worker.

We suppose that households are not able to finance their investment in human capital because of legal restraints on the appropriability of human capital and, thus, education has to be funded by the regional government by taxing working households residing in the region. ${ }^{7}$ For this, the government has two taxes at its disposal, a per capita tax on skilled and unskilled households, $t_{h}$ and $t_{l} .{ }^{8}$ Each household uses the entire net income to consume private goods $c_{h}$ and $c_{l}$, respectively. Thus, the private

\footnotetext{
${ }^{6}$ In the following, subindex $h$ denotes skilled labor while subindex $l$ marks unskilled labor, respectively.

${ }^{7}$ Financing education by taxation is the predominant way at least in all countries of the EU. One might also assume that the regional government could also charge workers directly for the cost of acquiring skills. But this assumption would also imply either that households have sufficient nonhuman capital to finance their own human capital investment before they work or that the government may effectively circumvent the prohibitions on contracts in which a household pawn her future earnings in exchange for present resources to finance her education. In the second case the government implements or at least supplant a perfect capital market.

${ }^{8}$ The possibility to tax households according to their skill-level reflects - in a very simple way - a progressive tax system.
} 
budget constraints are

$$
c_{i}=w_{i}-t_{i}, \quad i=h, l .
$$

All households have identical concave utility functions $u\left(c_{i}\right), \partial u\left(c_{i}\right) / \partial c_{i} \equiv u^{\prime}\left(c_{i}\right)>0$, $\partial^{2} u\left(c_{i}\right) / \partial c_{i}^{2} \equiv u^{\prime \prime}\left(c_{i}\right) \leq 0, i=h, l$, defined over its consumption of private goods as a skilled worker $c_{h}$ and unskilled worker $c_{l}$, respectively. The good's price is normalized to unity.

Since a household cannot be forced to acquire skills when she or he will be worse off by additional education, $c_{h}<c_{l}$, a household chooses to get educated until

$$
u\left(c_{h}\right) \geq u\left(c_{l}\right) \quad \Leftrightarrow \quad c_{h} \geq c_{l}
$$

is achieved. A government has to keep this constraint in mind when deciding on its optimal education policy.

Production of the private consumption good takes place by a linear-homogenous production function $F\left(L_{h}, L_{l}\right)$ using skilled labor $L_{h}$ and unskilled labor $L_{l}$. The production function fulfills the INADA conditions and is strictly concave with positive but diminishing marginal productivities in both factors. All markets are perfectly competitive and all workers are paid according to their marginal products,

$$
\frac{\partial F}{\partial L_{h}} \equiv F_{h}=w_{h}, \quad \frac{\partial F}{\partial L_{l}} \equiv F_{l}=w_{l} .
$$

Furthermore, all markets clear. Let $N_{h}$ denotes the number of native skilled households and $N_{l}$ the number of native unskilled households, respectively. In a closed economy the number of skilled and unskilled workers used in production is equal to the number of skilled and unskilled households, $N_{h}=L_{h}$ and $N_{l}=L_{l}$, and all native households are either skilled or unskilled,

$$
N=N_{h}+N_{l}
$$

Before describing governments decisions, it is instructive to analyze the condition for optimal investment in human capital maximizing total output. For this, a central planner would have to maximize total production minus education costs, $F\left(N_{h}, N_{l}\right)-$ $N_{h} e$, subject to the resource constraint $N_{l}=N-N_{h}$ by choosing $N_{h}$ yielding the first-order condition

$$
F_{h}-e=F_{l} .
$$


Thus, production efficiency is met if the marginal product of an additional skilled worker is just high enough to compensate for her or his education costs. ${ }^{9}$

\subsection{Benevolent government's policy}

Since skill acquisition occurs prior to working, government has to pre-finance human capital investment for native households. Furthermore, the government decides whether to restrict the access to the public education system and control the number of skilled native households $N_{h}$. This may be done directly by setting enrollment contingents at public educational institutions, or indirectly by assigning the level of critical inputs such as the number of staff employed. ${ }^{10}$

Of course, the choice of government's policy hinges crucially on the objective function guiding government's decision. First, the choice about the number of skilled households are made ex ante and the ex ante residents are, by definition, natives. Therefore, it makes sense to suppose that expenditure policy should reflect the interests of native population. Second, since all households are initially identical we assume that a government has no specific preference for skilled or unskilled native households when deciding on its policy. Thus, it is reasonable to presume that a benevolent government maximizes the utilitarian social welfare function ${ }^{11}$

$$
N_{h} u\left(c_{h}\right)+N_{l} u\left(c_{l}\right)
$$

Public expenditures of a benevolent government consists only of total education costs $N_{h} e$. These expenditures must be financed by taxes on working households

\footnotetext{
${ }^{9}$ Since we assume in the following that households acquire their skills in their region of birth, condition (5) also characterizes the efficient investment in human capital in a small open economy with mobile workers. Note that in this framework condition (5) is also fulfilled in a laissez-faire equilibrium with unrestricted access to education which must be financed privately. C.f. Wildasin (2000b) and Wellisch (2002).

${ }^{10} \mathrm{~A}$ further way to restrict the access to public education system exists by setting minimum admission requirements as, for example, marks of students. But this is not captured by the following analytical framework, since all households are assumed to be identical initially.

${ }^{11}$ This assumption may be even more justified if policy is made under uncertainty from behind a "veil of ignorance" as in Wildasin (2000b). Note that the utilitarian welfare function also subsumes values of society regarding inequality and justice. C.f. Cowell (1995).
} 
residing in the region. Thus, government's budget constraint reads as

$$
L_{h} t_{h}+L_{l} t_{l}=N_{h} e
$$

After the government has chosen taxes and has decided whether to restrict the access to the education system, households decide whether they acquire skill, so that the constraint (2) is always relevant for government's decision.

The government maximizes (6) subject to the budget constraints (1) and (7), taking into account (3) and (4), by choosing $t_{h}, t_{l}$, and $N_{h}$. Solving the government's problem yields ${ }^{12}$

$$
\begin{aligned}
c_{h} & =c_{l}, \\
t_{h} & =e, \text { and } t_{l}=0 .
\end{aligned}
$$

Condition (8) reveals that, in a closed economy, a benevolent government does not restrict the access to skill acquisition and ensure the same utility level for all households. Furthermore, condition (9) states that the government chooses the tax schedule so that only skilled households have to bear the costs of education. Finally, using (8), (9), and the private budget constraint (1) together with (3) gives

$$
F_{h}-e=F_{l}
$$

Hence, in a closed economy a benevolent government achieves an efficient level of human capital investment. ${ }^{13}$

\subsection{Partly selfish government's policy}

Beside the benevolent government approach there exists a sharply different view of government policy-making. Following Niskanen (1971), politicians do not seek to maximize the welfare of their residents, but to maximize their tax revenues in order to finance public expenditure which only benefits themselves.

\footnotetext{
${ }^{12}$ For a detailed derivation, see Appendix 1.

${ }^{13}$ As shown by Wildasin (2000b) and Wellisch (2002), the optimal education policy of a benevolent government replicates the outcome in a laissez-faire equilibrium with unrestricted access to privately financed education.
} 
In this section we partially incorporate this perception of policy-making and follow the studies of Edwards and Keen (1996) and Hange and Wellisch (1998) supposing that governments are neither entirely benevolent nor fully self-interested. On the one hand, a government maximizes the welfare of all native residents reflecting, for example, that politicians want to get reelected and hence have to bear their voters' utility in mind. On the other hand, politicians finance public expenditure $Z$ which benefits solely the policy-makers. From the viewpoint of a representative household this part of government expenditure is wasted. Thus, we have to rewrite the government budget constraint as

$$
L_{h} t_{h}+L_{l} t_{l}=N_{h} e+Z
$$

We describe politicians' preferences for $Z$ by the function $V(Z)$ which exhibits positive but diminishing marginal utility, $\partial V / \partial Z \equiv V^{\prime}(Z)>0, \partial^{2} V / \partial Z^{2} \equiv V^{\prime \prime}(Z)<0$. Now, the government's objective function reads as ${ }^{14}$

$$
N_{h} u\left(c_{h}\right)+N_{l} u\left(c_{l}\right)+V(Z) .
$$

The partly selfish government's problem is to maximize (12) subject to (11), by choosing $t_{h}, t_{l}, N_{h}$, and $Z$, and taking into account that $c_{i}$ and $N_{l}$ are as defined by (1), (3), and (4).

The first order conditions for this problem are: ${ }^{15}$

$$
\begin{aligned}
c_{h} & =c_{l}, \\
V^{\prime}(Z) & =u^{\prime}\left(c_{h}\right)=u^{\prime}\left(c_{l}\right) \\
t_{h} & =e+\frac{Z}{N}, \text { and } t_{l}=\frac{Z}{N} .
\end{aligned}
$$

Condition (13) shows that, for a given amount of wasteful expenditures $Z$, the government does not restrict the skill acquisition, ensuring the same consumption possibilities for all households. However, this does not mean that a partly self-interested government ensures the same consumption level as a benevolent government. As

\footnotetext{
${ }^{14}$ Adding $V(Z)$ up to the utilitarian welfare function $N_{h} u\left(c_{h}\right)+N_{l} u\left(c_{l}\right)$ does not only eases the analysis, but allows for a direct comparison to the purely benevolent government outcome.

${ }^{15} \mathrm{~A}$ detailed analysis may be found in Appendix 2.
} 
long as politicians are partly selfish, they use some resources for their own purposes, shrinking the consumption possibilities for all residents. Condition (14) describes how resources are distributed between the selfish policy-makers and the citizens. In the optimum, marginal benefit of increasing $Z$ must be equal to the marginal costs given by the decrease of the utility level of a skilled or unskilled household $u^{\prime}\left(c_{i}\right)$, $i=h, l$. The optimal tax policy is given by condition (15). As in the case of a benevolent government, skilled workers have to bear the whole costs of their education. Beyond, each household pays the amount of $Z / N$, financing wasteful expenditures.

Inserting the private budget constraints (1) together with (3) in (13) and using condition (15) yields

$$
F_{h}-e=F_{l}
$$

Thus, a partly selfish government chooses also an efficient level of investment in human capital guaranteeing the highest amount of resources for the whole economy. But, since policy makers use some of the resources for their own benefit, consumption levels of native households are lower than in the benevolent government case. This may be summarized in

Proposition 1: In a closed economy with publicly financed education, government's policy ensures an efficient allocation of skill acquisition and equalizes net incomes of skilled and unskilled households. A benevolent government taxes only skilled workers who have to bear their costs of education $t_{h}=e$. In addition, a partly selfish government reduces the consumption of their residents equally by the amount of $Z / N$ to finance its wasteful expenditures.

\section{Education policy with mobile skilled labor}

One of the most universal mobility relationships is that the propensity to migrate increases with education. ${ }^{16}$ To capture this scenario, consider the case where all small jurisdictions are connected by a common market for skilled labor. Therefore, the number of skilled labor employed in one jurisdiction $L_{h}$ is not determined by

\footnotetext{
${ }^{16}$ Empirical evidence and studies are presented by Greenwood (1997).
} 
the number of educated native households, $N_{h}$. In contrast, unskilled households are immobile, and the number of unskilled workers is equal to the number of unskilled native households, $L_{l}=N_{l}=N-N_{h}$.

As employers do not discriminate against immigrant skilled workers, they earn the same wage as native skilled workers, $w_{h}=F_{h}$. Moreover, we assume that the government fiscally treats immigrants and native skilled households in the same way. ${ }^{17}$ Thus, all skilled households within the region receive the same (gross) wage and have to pay the same tax $t_{h}$.

All skilled households are assumed to be able to migrate at no costs from their home region to another. ${ }^{18}$ If a skilled household settles outside the region she or he attains a (net) income $\omega_{h}$, taken as given by all agents. Skilled households will only reside in their home region if they get at least this reservation income. Hence, the migration equilibrium is characterized by identical consumption possibilities within and outside the region for mobile skilled workers,

$$
c_{h}=F_{h}-t_{h}=\omega_{h} .
$$

Differentiating (17) with respect to $t_{h}$ and taking into account that $\omega_{h}$ is fixed from the agents' point of view, yields the wage response with regard to taxing skilled households as

$$
\frac{d F_{h}}{d t_{h}}=1
$$

Thus, if the government raises $t_{h}$, skilled households will leave the region until the reduction in their income $d t_{h}$, is fully offset by an equivalent wage increase $d F_{h}$. From the government's perspective consumption possibilities of skilled households do not alter with its taxing policy.

\footnotetext{
${ }^{17}$ This assumption reflects the situation within the European Union. There, Article 48 of the European Treaty on the EU prohibits a different national or regional treatment of citizens coming from other EU countries with respect to their fiscal status.

${ }^{18}$ This assumption of perfect mobility made for analytical convenience seems to be very strong. More realistically, migration costs could be included. As long as these costs are not prohibitively high, they will not qualitatively change, but only weaken the results.
} 


\subsection{Benevolent government's behavior}

Integration of labor markets significantly changes government's education policy. Fearing the flight of the tax bases, governments are forced to cut down their taxes on mobile factors. Thus, the mobility of skilled households constrains the mix of taxes a government will choose. As will be shown in this section, the equilibrium level of education will also be affected.

To analyze this, we follow Wildasin (2000b) and Wellisch (2002) and assume that households acquire their skills in the home region. Hence, skilled workers coming from abroad cause no costs to the education system in their host region. In fact, the education cost has to be borne by the region where they grew up. ${ }^{19}$

As in the previous section, we assume that the government chooses the optimal education policy ex ante and therefore maximizes the utilitarian social welfare function (6) including only the utility of native households. ${ }^{20}$ Maximizing (6) subject to the private budget constraints of skilled and unskilled native households, (17) and (1) together with (3), and the government's budget constraint (7) by choosing $t_{h}, t_{l}$ and $N_{h}$ and taking into account that $N_{l}=N-N_{h}$ gives the optimal education policy of a benevolent government as ${ }^{21}$

$$
\begin{aligned}
t_{h} & =0, \quad \text { and } t_{l}=\frac{N_{h} e}{N_{l}}, \\
u\left(c_{h}\right)-u\left(c_{l}\right) & =u^{\prime}\left(c_{l}\right)\left(t_{l}+e\right) .
\end{aligned}
$$

Condition (19) replicates the well-known result in the literature on fiscal fedearlism

\footnotetext{
${ }^{19}$ To saddle emigrating skilled households at least partly with their education cost in the home country, exit fees in the spirit of a brain drain tax as suggested by Bhagwati (1976) and Bhagwati and Partington (1976) may be reasonable. Such an exit fee is prohibited within the US as well as within the EU (c.f. Article 48 of the European Treaty) since this tax would impede free mobility of labor.

${ }^{20}$ One may argue that welfare is depending on skilled and unskilled workers residing in the region, $L_{h} u\left(c_{h}\right)+N_{l} u\left(c_{l}\right)$. This would not change any of the forthcoming results regarding the optimal tax policy. Since utility of skilled workers is determined by $\omega_{h}$ and exogenously given from the government's point of view, tax policy only affects the utility of unskilled native households. Thus, in fact, for a given level of investment in human capital $N_{h} e$, tax policy is chosen to maximize the net income of the unskilled workers.

${ }^{21}$ For a detailed derivation, see Appendix 3.
} 
that governments abstain from taxing mobile factors if they can impose a tax on immobile factors. ${ }^{22}$ Thus, governments competing for mobile skilled workers fully finance their education policy by taxes on immobile unskilled workers. ${ }^{23}$

This result influences the optimal investment policy in human capital. Since $t_{h}=0$ and $\omega_{h}$ is given from the government's point of view, the marginal productivity of skilled labor must also be taken as given by the regional government, $F_{h}=\omega_{h}$. Due to the properties of a linear-homogeneous production function, the gross wage of unskilled labor is also exogenously given. Hence, if the government levies taxes that allow its citizens to become skilled and earn $\omega_{h}$ it has to harm unskilled workers. In equilibrium, public education policy has to make unskilled households worse off than skilled workers in order to increase welfare. Formally, the optimal investment policy in human capital is described by condition (20). The utility difference $u\left(c_{h}\right)-u\left(c_{l}\right)$ on the left hand side gives the marginal welfare benefit of an additional skilled native household. But educating one more native household causes two kinds of cost stated on the right hand side of (20). First, government's expenditures increase by the education costs $e$, and, second, this reduces the number of unskilled taxpaying natives, each of whom is paying taxes in the amount of $t_{l}$. Summarizing, the net fiscal marginal costs add to $t_{l}+e$, which must be borne by unskilled natives. Evaluating this loss by the marginal utility of an unskilled worker gives the marginal welfare cost of an additional skilled native household. ${ }^{24}$

To ensure that the education policy makes skilled households better off than unskilled workers, $c_{h}>c_{l}$, the government has to restrict the access to the publicly provided education system for natives. Does this policy also lead to an inefficient level of human capital investment? Following Wildasin (2000b) the answer is yes, as long as the utility function $u(c)$ is strictly concave, $u^{\prime \prime}(c)<0$, and the utilitarian welfare function features, thus, some degree of inequality aversion. Intuitively, some

\footnotetext{
${ }^{22}$ C.f. Sinn (1997) and Wellisch (2000). Note that this result holds independently on the size of economies. Thus, the assumption of small open economies, while simplifying the formal analysis, does not alter the basic insights.

${ }^{23}$ It is worth to emphasize once again, that this policy is in the interest of the immobile unskilled workers, too.

${ }^{24}$ Since the right hand side of (20) is strictly positive for $N_{h}>0$, the utility differential on the left hand side must also be positive, formally proofing the above mentioned intuition.
} 
degree in the efficiency of human capital investment is sacrificed in order to reduce the income differences between skilled and unskilled native households and to achieve a more equal income distribution.

Formally, this may be seen by using the instrument of Taylor expansions. As we know from (5), efficiency is characterized by $F_{h}-e=F_{l}$ or $F_{h}=F_{l}+e$, respectively. Since in the case of perfectly mobile skilled households $u\left(c_{h}\right)=u\left(F_{h}\right)$, efficiency would require $u\left(F_{h}\right)=u\left(F_{l}+e\right)$. Approximating $u\left(F_{l}+e\right)$ at $F_{l}-t_{l}$ yields

$$
\begin{aligned}
u\left(F_{l}+e\right) & =u\left(F_{l}-t_{l}\right)+u^{\prime}\left(F_{l}-t_{l}\right)\left[F_{l}+e-\left(F_{l}-t_{l}\right)\right] \\
& +\frac{1}{2} u^{\prime \prime}\left(F_{l}-t_{l}\right)\left[F_{l}+e-\left(F_{l}-t_{l}\right)\right]^{2}+\ldots \\
& =u\left(c_{l}\right)+u^{\prime}\left(c_{l}\right)\left(e+t_{l}\right)+\frac{1}{2} u^{\prime \prime}\left(c_{l}\right)\left(e+t_{l}\right)^{2}+\ldots
\end{aligned}
$$

Comparing this to condition (20) reveals that the equilibrium level of skilled natives with publicly financed human capital and perfectly mobile skilled households must be less than efficiency demands: ${ }^{25}$

$$
u\left(c_{h}\right)=u\left(F_{h}\right)=u\left(c_{l}\right)+u^{\prime}\left(c_{l}\right)\left(e+t_{l}\right)>u\left(F_{l}+e\right) \quad \Rightarrow \quad F_{h}>F_{l}+e .
$$

\subsection{Partly selfish government's behavior}

Following the procedure as above, a partly self-interested government maximizes $N_{h} u\left(c_{h}\right)+N_{l} u\left(c_{l}\right)+V(Z)$ subject to the budget constraints (1) together with (3), (11), and (17) with regard to $t_{h}, t_{l}$, and $N_{h}$. Solving this yields the first order conditions $^{26}$

$$
t_{h}=0, \quad \text { and } \quad t_{l}=\frac{N_{h} e+Z}{N_{l}},
$$

\footnotetext{
${ }^{25}$ As shown by Wildasin (2000b, p. 89), the inefficiency hinges crucially on the inequality aversion. To see this suppose a linear utility function, e.g., $u\left(c_{i}\right)=\alpha+\beta c_{i}, i=h, l$, and, thus, a utilitarian welfare function which is neutral with regard to inequality. Using this function in (20) reveals that $F_{h}=F_{l}+e$ and education policy ensures an efficient investment in human capital. Of course, this does not mean that net income of skilled and unskilled households are equal, since unskilled workers have to finance public education. But the government restricts the access to the education system in an efficient way.

${ }^{26}$ Once more, the explicit derivation may be found in Appendix 4.
} 


$$
\begin{aligned}
V^{\prime}(Z) & =u^{\prime}\left(c_{l}\right), \\
u\left(c_{h}\right)-u\left(c_{l}\right) & =u^{\prime}\left(c_{l}\right)\left(t_{l}+e\right) .
\end{aligned}
$$

Condition (22) reveals that, as a benevolent government, partly selfish politicians abstain from taxing mobile households and that government's expenditures are fully financed by taxing immobile unskilled workers. A partly self-interested government uses some resources for its own consumption, $Z$. According to (23), politicians will increase $Z$ until the marginal benefit $V^{\prime}(Z)$ equals the marginal cost given by the marginal utility of unskilled households $u^{\prime}\left(c_{l}\right)$, since utility of skilled households are given from the government's perspective.

As is shown by condition (24) mimicking (20), partly selfish politicians also restrict the access to the publicly financed education system and have to make unskilled households worse off than skilled workers. The optimal number of skilled natives is achieved when marginal benefit of educating one further native is equal to the marginal costs consisting of additional education costs $e$ and the gone tax payments $t_{l}$. Note that for a given number of skilled native households the marginal costs as well as the marginal benefit are higher than in the benevolent government's case. On the one hand an additional gone tax paying unskilled worker finances not only the educational system but also government's consumption $Z$, increasing the marginal costs. But since unskilled households have to finance the whole government's expenditure, the utility difference, $u\left(c_{h}\right)-u\left(c_{l}\right)$ and thus the marginal benefit is also higher than in the benevolent government's case.

Does higher marginal cost and benefit in educating native households also result in a lower investment in human capital compared to the benevolent government's case? To gain some first insight, note that investment in human capital of native households will be inefficiently low, if the welfare function is characterized by inequality aversion, described by a strictly concave utility function, as in the case of a benevolent government. ${ }^{27}$ But, since for a given number of skilled natives, the difference in net incomes of skilled and unskilled households is larger under the partly-selfish policy regime than in the benevolent government's case due to the

\footnotetext{
${ }^{27}$ It is obvious that partly selfish politicians would restrict the access to the public education system in an efficient way if the utility function is linear, c.f. footnote 25 .
} 
additional burden of financing government's wasteful consumption, the sacrifice in efficiency of human capital investment may be also higher to reduce income inequality. Hence, in general, partly selfish politicians will invest less in education than a benevolent government. In order to derive this formally, we use (24) together with (22) to express $N_{h}$ as an implicit function of $Z$ :

$$
\begin{aligned}
H\left(N_{h}, Z\right) & =u\left(F_{h}\right)-u\left(F_{l}-\frac{N_{h} e+Z}{\left(N-N_{h}\right)}\right) \\
& -u^{\prime}\left(F_{l}-\frac{N_{h} e+Z}{\left(N-N_{h}\right)}\right)\left(\frac{N_{h} e+Z}{\left(N-N_{h}\right)}+e\right),
\end{aligned}
$$

where the private budget constraints (1) and (17) have been inserted. Recall that in a small open economy $F_{h}$ as well as $F_{l}$ are taken as given. Now, using the implicit function theorem, we get

$$
\frac{d N_{h}}{d Z}=-\frac{1}{t_{l}+e}<0,
$$

revealing that the number of skilled native households is decreasing with increasing wasteful expenditures by politicians. To summarize, we have the following

Proposition 2: In a small open economy with perfectly mobile skilled households politicians abstain from taxing mobile households shifting the whole tax burden on unskilled native workers. This results in an unequal net income distribution by making unskilled workers worse off than skilled workers. Thus, the government has to restrict the access to the education system. If the government is inequality averse, public education results in an inefficient low investment in human capital. Compared to a benevolent regime, a partly self-interested government restricts the access to public education even more.

\section{Education policy with mobile unskilled labor}

While the link between education and migration propensity is a well-established empirical result, the public and political debate often stresses that the bulk of mobile households are unskilled workers. Especially, following the discussion on EU enlargement to the East or establishing NAFTA between US and Mexico, it has be- 
en argued that mainly unskilled households migrate towards the EU and US driven mostly by income differentials between countries or regions.

In order to analyze this scenario, consider a small open economy taking the net return of perfectly mobile unskilled workers as exogenously given,

$$
c_{l}=F_{l}-t_{l}=\omega_{l}
$$

Now, the number of unskilled workers $L_{l}$ is not determined by the number of unskilled natives, $N_{l}=N-N_{h}$, but the number of skilled workers, $L_{h}=N_{h}$. As in the previous section, employers as well as government do not discriminate against immigrating unskilled workers. Hence, they receive the same gross wage $F_{l}$ and pay the same tax $t_{l}$.

\subsection{Benevolent government's policy}

If the government maximizes the utilitarian welfare function (6) subject to its budget constraint (7), taking into account the private budget constraints (1), (3), (27), and the fact that it cannot influence the net return of mobile unskilled labor, the first order conditions are given by $^{28}$

$$
\begin{aligned}
t_{l} & =0, \text { and } t_{h}=e, \\
c_{h} & =c_{l} .
\end{aligned}
$$

If unskilled workers are perfectly mobile the government taxes only immobile skilled households, as reflected by condition (28). Thus, skilled workers bear their own education costs. Furthermore, as is shown by (29), the government does not restrict the access to public education guaranteeing the same net income for skilled and unskilled households. Using (28) and the private budget constraints in (29) reveals, that this policy also ensures an efficient human capital investment, $F_{h}-e=F_{l}{ }^{29}$

\footnotetext{
${ }^{28}$ An explicit solution is shown in the Appendix 5.

${ }^{29}$ It is worth noting, that this policy is also optimal, if the government is only interested in the welfare of their native skilled households, because it maximizes the net income of immobile households.
} 


\subsection{Partly selfish government's policy}

Finally, we take a look on the optimal education policy of partly self-interested politicians in the case of perfectly mobile unskilled households. The government maximizes (12) subject to its budget constraint (11), the private budget constraints, taking into account that the net return on mobile households are exogenously given from the government's perspective. Solving the government's problem yields the following first order conditions: ${ }^{30}$

$$
\begin{aligned}
t_{l} & =0, \quad \text { and } \quad t_{h}=e+\frac{Z}{N_{h}}, \\
V^{\prime}(Z) & =u^{\prime}\left(c_{h}\right), \\
u\left(c_{l}\right) & -u\left(c_{h}\right)=V^{\prime}(Z) \frac{Z}{N_{h}} .
\end{aligned}
$$

Not astonishingly, according to (30) a partly selfish government also resigns to tax mobile workers. Thus, skilled immobile households have to fully finance their education as well as government's wasteful expenditure. Condition (31) describes that the government will increase its wasteful consumption until the marginal benefit $V^{\prime}(Z)$ is equal to the marginal costs. Since utility of unskilled households are taken as given, marginal costs are characterized by the decrease of the utility level of a skilled household $u^{\prime}\left(c_{h}\right)$.

Finally, condition (32) reveals, that partly selfish politicians would like to make skilled households worse off than unskilled workers in order to broaden the tax base financing education and government's wasteful expenditures. ${ }^{31}$ But, according to (2), the government can never force households to acquire skills if they may be worse off by this. Since this constraint is binding, the best the government can do is not to restrict the access to the public education system guaranteeing the same consumption level for all households,

$$
c_{h}=c_{l}
$$

\footnotetext{
${ }^{30}$ Appendix 6 presents an explicit solution.

${ }^{31}$ Now, the left hand side of (32) denotes the marginal (welfare) costs of educating one additional household reducing her utility by the amount of $u\left(c_{l}\right)-u\left(c_{h}\right)$, whereas the right hand side represents the marginal benefit of an additional taxpayer from the government's point of view.
} 
Inserting the private budget constraints into (33) and using (30) we get

$$
F_{h}-t_{h}=F_{l} \quad \Longrightarrow \quad F_{h}-e>F_{l} \text {. }
$$

Hence, as long as politicians use some tax revenues for their own purposes, government's policy has to ensure that gross income of skilled households must exceed marginal productivity of unskilled labor by more than education costs. This behavior results in an inefficient low level of investment in human capital, and we get

Proposition 3: In a small open economy with perfectly mobile unskilled households politicians abstain from taxing mobile households, shifting the whole tax burden on skilled native workers. Government never restricts the access to the education system and all households receive the same net income. In contrast to the benevolent government's case, partly selfish politicians cause an inefficiently low investment in human capital.

\section{Concluding remarks}

Politicians as well as economists are aware of two major insights. First, education of citizens may be essential to foster national income and growth. Second, due to economic integration and increasing factor mobility, tax bases become less available to finance public expenditures. This paper deals with both topics using a very simplified and stylized model building on Wildasin's work (2000b) and presents some basic insights one may learn about education policy in the presence of mobile households. A first lesson is that economic integration of labor markets drives governments to abstain from taxing mobile factors but shifts the whole burden to the immobile workers. In the case of mobile skilled workers, this results in higher net incomes for skilled workers. Furthermore, if politicians are inequality averse, the level of investment in human capital is inefficiently low. This is even more pronounced when politicians are partly self-interested and capture some of the tax revenues for own purposes.

In contrast, if markets for unskilled labor are integrated the net incomes of households will be equalized. Furthermore, a benevolent government faces the right 
incentives to choose an efficient level of human capital investment. Partly selfish politicians, however, invest too little in educating their citizens. In order to use some resources for their own consumption, they have to guarantee that the marginal productivity of skilled labor exceeds that of unskilled workers by more than the education costs.

Of course, there are many ways the simple analysis in this paper may be expanded. Since human capital is one of the major forces driving economic growth, it seems of particular interest to incorporate the above mentioned ideas in an explicitly dynamic framework to investigate the impact of public education policy on the growth path. ${ }^{32}$ Furthermore, while in the present paper labor markets are assumed to be perfectly competitive, it seems to be worthwhile to investigate education policy in the presence of labor market imperfections. Following the contributions by Fuest and Huber (1999), Richter and Schneider (2001), or Koskela and Schöb (2002) dealing with optimal factor taxation in the presence of unemployment and mobile capital, it may be expected, that mobile workers should be taxed reducing the burden for immobile households and turning the conventional wisdom that mobile factors should not be taxed on its head. ${ }^{33}$ The question how education policy may be affected remains open.

\footnotetext{
${ }^{32}$ There exists already an increasing literature on education policies and growth, e.g. summarized by Aghion and Howitt (1998), but most of them neglecting mobility of human capital across economies.

${ }^{33}$ See also Fuest and Thum (2001) for a similar discussion. However, in contrast to the present paper, they only analyze the case of privately financed education and immigration which is exogenously given.
} 


\section{Appendix}

\section{Appendix 1. Derivation of (8) and (9)}

Using (4), and the private budget constraints (1), the benevolent government's problem in the close economy gives the Lagrangean

$$
\mathcal{L}=N_{h} u\left(F_{h}-t_{h}\right)+\left(N-N_{h}\right) u\left(F_{l}-t_{l}\right)+\mu\left[N_{h} t_{h}+\left(N-N_{h}\right) t_{l}-N_{h} e\right] .
$$

Maximizing with respect to $t_{h}, t_{l}$, and $N_{h}$ gives the first-order conditions

$$
\begin{aligned}
\frac{\partial \mathcal{L}}{\partial t_{h}} & =0 \Rightarrow u^{\prime}\left(c_{h}\right)=\mu \\
\frac{\partial \mathcal{L}}{\partial t_{l}} & =0 \Rightarrow u^{\prime}\left(c_{l}\right)=\mu \\
\frac{\partial \mathcal{L}}{\partial N_{h}} & =u\left(c_{h}\right)+N_{h} u^{\prime}\left(c_{h}\right) \frac{d F_{h}}{d N_{h}} \\
& -u\left(c_{l}\right)+N_{l} u^{\prime}\left(c_{l}\right) \frac{d F_{l}}{d N_{l}}+\mu\left(t_{h}-t_{l}-e\right)=0 .
\end{aligned}
$$

From (A.1) and (A.2) it follows immediately that $c_{h}=c_{l}$ and, therefore, (8) in the case of identical utility functions. Using this result and the property of a linearhomogeneous production function, i.e.

$$
d F_{h} L_{h}+d F_{l} L_{l}=0 \Rightarrow \frac{d F_{l}}{d L_{h}}=-\frac{d F_{h}}{d L_{h}} \frac{L_{h}}{L_{l}},
$$

(A.3) becomes $t_{h}-e=t_{l}$. Inserting this in the budget constraint of the government (7) gives condition (9).

\section{Appendix 2. Derivation of (13)-(15)}

With partly selfish politicians the government's problem may be described by solving the Lagrangean

$\mathcal{L}=N_{h} u\left(F_{h}-t_{h}\right)+\left(N-N_{h}\right) u\left(F_{l}-t_{l}\right)+V(Z)+\mu\left[N_{h} t_{h}+\left(N-N_{h}\right) t_{l}-N_{h} e-Z\right]$

by choosing $t_{h}, t_{l}, Z$, and $N_{h}$ yielding

$$
\frac{\partial \mathcal{L}}{\partial t_{h}}=0 \Rightarrow u^{\prime}\left(c_{h}\right)=\mu,
$$




$$
\begin{aligned}
\frac{\partial \mathcal{L}}{\partial t_{l}} & =0 \Rightarrow u^{\prime}\left(c_{l}\right)=\mu \\
\frac{\partial \mathcal{L}}{\partial Z} & =0 \Rightarrow V^{\prime}(Z)=\mu \\
\frac{\partial \mathcal{L}}{\partial N_{h}} & =u\left(c_{h}\right)+N_{h} u^{\prime}\left(c_{h}\right) \frac{d F_{h}}{d N_{h}} \\
& -u\left(c_{l}\right)+N_{l} u^{\prime}\left(c_{l}\right) \frac{d F_{l}}{d N_{l}}+\mu\left(t_{h}-t_{l}-e\right)=0 .
\end{aligned}
$$

As in the benevolent government's case, (A.5) and (A.6) reveal immediately that $c_{h}=c_{l}$ and thus condition (13). Furthermore, inserting (A.7) in (A.5) and (A.6) gives condition (14). Finally, using the property of a linear-homogenous production function (A.4), (A.8) yields $t_{h}=t_{l}+e$. Inserting this into the budget constraint of a partly selfish government (11) gives the optimal taxes (15).

\section{Appendix 3. Derivation of (19) and (20)}

In the case of perfectly mobile skilled labor the benevolent government maximizes the Lagrangean

$$
\mathcal{L}=N_{h} u\left(\omega_{h}\right)+\left(N-N_{h}\right) u\left(F_{l}-t_{l}\right)+\mu\left[L_{h} t_{h}+\left(N-N_{h}\right) t_{l}-N_{h} e\right] .
$$

by choosing $t_{h}, t_{l}$, and $N_{h}$. This results in the first order conditions

$$
\begin{aligned}
\frac{\partial \mathcal{L}}{\partial t_{h}} & =N_{l} u^{\prime}\left(c_{l}\right) \frac{d F_{L}}{d L_{h}} \frac{d L_{h}}{d t_{h}}+\mu\left(L_{h}+t_{h} \frac{d L_{h}}{d t_{h}}=0\right), \\
\frac{\partial \mathcal{L}}{\partial t_{l}} & =0 \Rightarrow u^{\prime}\left(c_{l}\right)=\mu, \\
\frac{\partial \mathcal{L}}{\partial N_{h}} & =u\left(c_{h}\right)-u\left(c_{l}\right)-\mu\left(t_{l}+e\right)=0 .
\end{aligned}
$$

Since $N_{l}=L_{l}$, the property of the production function (A.4) becomes $-d F_{l} / d L_{h}=$ $\left(d F_{h} / d L_{h}\right)\left(L_{h} / N_{l}\right)$. Using this and (18) in (A.9) gives

$$
\mu t_{h} \frac{L_{h}}{d t_{h}}=0 .
$$

Since $d L_{h} / d t_{h}<0$ and $\mu>0, t_{h}=0$. Inserting this into the budget constraint of the benevolent government (7) yields $t_{l}=N_{h} e / N_{l}$ and thus (19). Finally, using 
(A.10) in (A.11) gives immediately (20).

\section{Appendix 4. Derivation of (22)-(24)}

With partly selfish politicians the government's problem may be described by solving the Lagrangean

$$
\mathcal{L}=N_{h} u\left(\omega_{h}\right)+\left(N-N_{h}\right) u\left(F_{l}-t_{l}\right)+V(Z)+\mu\left[N_{h} t_{h}+\left(N-N_{h}\right) t_{l}-N_{h} e-Z\right]
$$

by choosing $t_{h}, t_{l}, Z$, and $N_{h}$ yielding

$$
\begin{aligned}
\frac{\partial \mathcal{L}}{\partial t_{h}} & =N_{l} u^{\prime}\left(c_{l}\right) \frac{d F_{L}}{d L_{h}} \frac{d L_{h}}{d t_{h}}+\mu\left(L_{h}+t_{h} \frac{d L_{h}}{d t_{h}}=0\right), \\
\frac{\partial \mathcal{L}}{\partial t_{l}} & =0 \Rightarrow u^{\prime}\left(c_{l}\right)=\mu, \\
\frac{\partial \mathcal{L}}{\partial Z} & =0 \Rightarrow V^{\prime}(Z)=\mu, \\
\frac{\partial \mathcal{L}}{\partial N_{h}} & =u\left(c_{h}\right)-u\left(c_{l}\right)-\mu\left(t_{l}+e\right)=0 .
\end{aligned}
$$

Analogous to the benevolent government's case, (A.12) reveals that $t_{h}=0$. Inserting this into (11) yields $t_{l}=\left(N_{h} e+Z\right) / N_{l}$, and hence result (22) in the main text.

From (A.13) and (A.14) we get immediately condition (23). Finally, using (A.13) in (A.14) gives (24).

\section{Appendix 5. Derivation of (28) and (29)}

In the case of perfectly mobile unskilled labor, the benevolent government maximizes the Lagrangean

$$
\mathcal{L}=N_{h} u\left(\omega_{h}\right)+\left(N-N_{h}\right) u\left(F_{l}-t_{l}\right)+\mu\left[L_{h} t_{h}+\left(N-N_{h}\right) t_{l}-N_{h} e\right] .
$$

by choosing $t_{h}, t_{l}$, and $N_{h}$ yielding the first-order conditions

$$
\begin{aligned}
\frac{\partial \mathcal{L}}{\partial t_{h}} & =0 \Rightarrow u^{\prime}\left(c_{h}\right)=\mu, \\
\frac{\partial \mathcal{L}}{\partial t_{l}} & =N_{h} u^{\prime}\left(c_{h}\right) \frac{d F_{h}}{d L_{l}} \frac{d L_{l}}{d t_{l}}+\mu\left(L_{l}+t_{l} \frac{d L_{l}}{d t_{l}}=0\right), \\
\frac{\partial \mathcal{L}}{\partial N_{h}} & =u\left(c_{h}\right)-u\left(c_{l}\right)-\mu\left(t_{h}-e\right)=0 .
\end{aligned}
$$


Using the property of a linear-homogenous production function, $-d F_{h} / d L_{l}=$ $\left(d F_{l} / d L_{l}\right)\left(L_{l} / N_{h}\right),($ A.16) becomes

$$
\mu t_{l} \frac{d L_{l}}{d t_{l}}=0
$$

Since $\mu>0$ and $d L_{l} / d t_{l}<0, t_{l}=0$. Inserting this into the government's budget constraint (7), yields $t_{h}=e$ and thus condition (28). Using this result in (A.18) reveals that $u\left(c_{h}\right)=u\left(c_{l}\right)$ and thus condition (29).

\section{Appendix 6. Derivation of (30)-(32)}

With partly selfish politicians and perfectly mobile unskilled labor, the government's problem is to maximize

$$
\mathcal{L}=N_{h} u\left(\omega_{h}\right)+\left(N-N_{h}\right) u\left(F_{l}-t_{l}\right)+V(Z)+\mu\left[N_{h} t_{h}+\left(N-N_{h}\right) t_{l}-N_{h} e-Z\right]
$$

by choosing $t_{h}, t_{l}, Z$, and $N_{h}$ yielding the first order conditions

$$
\begin{aligned}
\frac{\partial \mathcal{L}}{\partial t_{h}} & =0 \Rightarrow u^{\prime}\left(c_{h}\right)=\mu \\
\frac{\partial \mathcal{L}}{\partial t_{l}} & =N_{h} u^{\prime}\left(c_{h}\right) \frac{d F_{h}}{d L_{l}} \frac{d L_{l}}{d t_{l}}+\mu\left(L_{l}+t_{l} \frac{d L_{l}}{d t_{l}}=0\right), \\
\frac{\partial \mathcal{L}}{\partial Z} & =0 \Rightarrow V^{\prime}(Z)=\mu \\
\frac{\partial \mathcal{L}}{\partial N_{h}} & =u\left(c_{h}\right)-u\left(c_{l}\right)-\mu\left(t_{h}-e\right)=0
\end{aligned}
$$

Analogous to the benevolent government's case, (A.20) reveals that $t_{l}=0$. Inserting this into (11) yields $t_{h}=e+Z / N_{h}$, and hence result (30) in the main text.

From (A.19) and (A.21) we get immediately condition (31). Finally, using (A.21) and (30) in (A.22) gives (32). 


\section{References}

Aghion P. and P. Howitt, 1998, Endogenous Growth Theory, MIT Press: Cambridge, Mass.

Andersson, F. and K. A. Konrad, 2001, Human capital investment and globalization in extortionary states, IZA Discussion paper 239.

Andersson, F. and K. A. Konrad, 2002, Globalization and human capital formation, IZA Discussion paper 245.

Bhagwati, J. N. (ed.) , 1976, The brain drain and taxation II: Theory and empirical analysis, Amsterdam: North-Holland.

Bhagwati, J. N. and M. Partington (eds.), 1976, Taxing the brain drain I: A proposal, Amsterdam: North-Holland.

Cowell, F. A., 1995, Measuring inequality, LSE Handbooks of Economics, 2nd edition.

Edwards, J. and M. Keen, 1996, Tax competition and Leviathan, European Economic Review 40, 113-134.

Fuest, C. and B. Huber, 1999, Tax coordination and unemployment, International Tax and Public Finance 6, 7-26.

Fuest, C. and C. Thum, 2001, Immigration and skill formation in unionised labour markets, European Journal of Political Economy 17, 557-573.

Greenwood, M.J., 1997, Internal migration in developed countries, in: M.R. Rosenzweig und O. Stark (Hrsg.), Handbook of Population and Family Economics, Vol. 1B, Amsterdam: Elsevier, S. 647-720.

Hange, U. and D. Wellisch, 1998, The benefit of fiscal decentralization, FinanzArchiv $55,315-327$.

Koskela, E. and R. Schb, 2002, Optimal factor income taxation in the presence of unemployment, Journal of Public Economic Theory 4, 387-404. 
Niskanen, W. A. Jr., 1971, Bureaucracy and representative government, Chicago: Aldine Publishing Company.

OECD, 2001, Education on a first glance, Paris.

Richter, W. F. and K. Schneider, 2001, Taxing mobile capital with labor market imperfections, International Tax and Public Finance 8, 245-262.

Sinn, H.-W., 1997, The selection principle and market failure in systems competition, Journal of Public Economics 66, 247-274.

Sinn, H.-W., 2002, The New Systems Competition, Yrj-Jahnsson Lectures, Basil Blackwell: Oxford.

Stiglitz, J. E., 2000, Economics of the public sector, 3rd edition, New York and London: W.W. Norton \& Company, Inc.

Wellisch, D., 2000, Theory of public finance in a federal state, Cambridge: Cambridge University Press.

Wellisch, D., 2002, Education policy and immigration - some basic insights, mimeo, University of Magdeburg.

Wellisch, D. und D.E. Wildasin, 1996, Decentralized income redistribution and immigration, European Economic Review 40, 187-217.

Wildasin, D.E., 1991, Income distribution in a common labor market, American Economic Review 81, 757-774.

Wildasin, D.E., 1998, Factor mobility and redistributive policy: local and international perspectives, in: P.B. Sørensen (Hrsg.), Public finance in a changing world, London: MacMillan, 151-192.

Wildasin, D.E., 2000a, Factor mobility and fiscal policy in the EU: Policy issues and analytical approaches, Economic Policy 31, pp. 339-378 .

Wildasin, D.E., 2000b, Labor-market integration, investment in risky human capital, and fiscal competition, American Economic Review 90, pp. 73-95. 


\title{
CESifo Working Paper Series
}

\author{
(for full list see www.cesifo.de)
}

869 M. Hashem Pesaran, Estimation and Inference in Large Heterogenous Panels with Cross Section Dependence, February 2003

870 Luis H. R. Alvarez and Erkki Koskela, On the Tree-Cutting Problem under Interest Rate and Forest Value Uncertainty, February 2003

871 Norbert Berthold and Rainer Fehn, Unemployment in Germany: Reasons and Remedies, February 2003

872 Clemens Fuest, Bernd Huber, and Philipp Tilleßen, Tax Policy and Entrepreneurship in the Presence of Asymmetric Information in Capital Markets, February 2003

873 Eytan Sheshinski, Optimum and Risk-Class Pricing of Annuities, February 2003

874 Willi Leibfritz, Paul O'Brien and Jean-Christophe Dumont, Effects of Immigration on Labour Markets and Government Budgets - An Overview, February 2003

875 M. Hashem Pesaran and Allan Timmermann, How Costly is it to Ignore Breaks when Forecasting the Direction of a Time Series?, February 2003

876 Thorvaldur Gylfason and Gylfi Zoega, Education, Social Equality and Economic Growth: A View of the Landscape, February 2003

877 Robin Boadway and Jean-François Tremblay, Public Economics and Startup Entrepreneurs, February 2003

878 Erkki Koskela and Roope Uusitalo, The Un-Intended Convergence: How the Finnish Unemployment Reached the European Level, February 2003

879 Robert Fenge and Volker Meier, Pensions and Fertility Incentives, February 2003

880 Eytan Sheshinski, Note on Income Taxation and Occupational Choice, February 2003

881 A B Atkinson, Income Inequality in OECD Countries: Data and Explanations, February 2003

882 Thomas Gehrig and Rune Stenbacka, Venture Cycles: Theory and Evidence, February 2003

883 Ralf Becker and Thomas Hellmann, The Genesis of Venture Capital - Lessons from the German Experience, March 2003

884 Eytan Sheshinski, Note on the Optimum Pricing of Annuities, March 2003 
885 Paul De Grauwe and Magdalena Polan, Globalisation and Social Spending, March 2003

886 F. van der Ploeg, Do Social Policies Harm Employment and Growth?, March 2003

887 Mirjam van Praag, Initial Capital Constraints Hinder Entrepreneurial Venture Performance: An empirical analysis, March 2003

888 Bernard Steunenberg, Coordinating Sectoral Policymaking: Searching for Countervailing Mechanisms in the EU Legislative Process, March 2003

889 Eytan Sheshinski, Optimum Delayed Retirement Credit, March 2003

890 Frederick van der Ploeg, Rolling Back the Public Sector - Differential effects on employment, investment and growth, March 2003

891 Paul De Grauwe and Marc-Alexandre Sénégas, Monetary Policy in EMU when the Transmission is Asymmetric and Uncertain, March 2003

892 Steffen Huck and Kai A. Konrad, Strategic Trade Policy and the Home Bias in Firm Ownership Structure, March 2003

893 Harry Flam, Turkey and the EU: Politics and Economics of Accession, March 2003

894 Mathias Hoffmann and Ronald MacDonald, A Re-examination of the Link between Real Exchange Rates and Real Interest Rate Differentials, March 2003

895 Badi H. Baltagi, Espen Bratberg, and Tor Helge Holmås, A Panel Data Study of Physicians' Labor Supply: The Case of Norway, March 2003

896 Dennis C. Mueller, Rights and Citizenship in the European Union, March 2003

897 Jeremy Edwards, Gains from Trade in Tax Revenue and the Efficiency Case for Trade Taxes, March 2003

898 Rainer Fehn and Thomas Fuchs, Capital Market Institutions and Venture Capital: Do They Affect Unemployment and Labour Demand?, March 2003

899 Ronald MacDonald and Cezary Wójcik, Catching Up: The Role of Demand, Supply and Regulated Price Effects on the Real Exchange Rates of Four Accession Countries, March 2003

900 R. Selten, M. Schreckenberg, T. Pitz, T. Chmura, and S. Kube, Experiments and Simulations on Day-to-Day Route Choice-Behaviour, April 2003

901 Stergios Skaperdas, Restraining the Genuine Homo Economicus: Why the Economy Cannot be Divorced from its Governance, April 2003

902 Yin-Wong Cheung, Menzie D. Chinn, and Antonio Garcia Pascual, What Do We Know about Recent Exchange Rate Models? In-Sample Fit and Out-of-Sample Performance Evaluated, April 2003 
903 Mika Widgrén, Enlargements and the Principles of Designing EU - Decision-Making Procedures, April 2003

904 Phornchanok Cumperayot, Dusting off the Perception of Risk and Returns in FOREX Markets, April 2003

905 Kai A Konrad, Inverse Campaigning, April 2003

906 Lars P. Feld and Stefan Voigt, Economic Growth and Judicial Independence: Cross Country Evidence Using a New Set of Indicators, April 2003

907 Giuseppe Bertola and Pietro Garibaldi, The Structure and History of Italian Unemployment, April 2003

908 Robert A.J. Dur and Otto H. Swank, Producing and Manipulating Information, April 2003

909 Christian Gollier, Collective Risk-Taking Decisions with Heterogeneous Beliefs, April 2003

910 Alexander F Wagner, Mathias Dufour, and Friedrich Schneider, Satisfaction not Guaranteed - Institutions and Satisfaction with Democracy in Western Europe, April 2003

911 Ngo Van Long, Raymond Riezman, and Antoine Soubeyran, Trade, Wage Gaps, and Specific Human Capital Accumulation, April 2003

912 Andrea Goldstein, Privatization in Italy 1993-2002: Goals, Institutions, Outcomes, and Outstanding Issues, April 2003

913 Rajshri Jayaraman and Mandar Oak, The Signaling Role of Municipal Currencies in Local Development, April 2003

914 Volker Grossmann, Managerial Job Assignment and Imperfect Competition in Asymmetric Equilibrium, April 2003

915 Christian Gollier and Richard Zeckhauser, Collective Investment Decision Making with Heterogeneous Time Preferences, April 2003

916 Thomas Moutos and William Scarth, Some Macroeconomic Consequences of Basic Income and Employment Subsidies, April 2003

917 Jan C. van Ours, Has the Dutch Miracle Come to an End?, April 2003

918 Bertil Holmlund, The Rise and Fall of Swedish Unemployment, April 2003

919 Bernd Huber and Marco Runkel, Optimal Design of Intergovernmental Grants under Asymmetric Information, April 2003

920 Klaus Wälde, Endogenous Business Cycles and Growth, April 2003 
921 Ramon Castillo and Stergios Skaperdas, All in the Family or Public? Law and Appropriative Costs as Determinants of Ownership Structure, April 2003

922 Peter Fredriksson and Bertil Holmlund, Improving Incentives in Unemployment Insurance: A Review of Recent Research, April 2003

923 Bernard M.S. van Praag and Adam S. Booij, Risk Aversion and the Subjective Time Discount Rate: A Joint Approach, April 2003

924 Yin-Wong Cheung, Kon S. Lai, and Michael Bergman, Dissecting the PPP Puzzle: The Unconventional Roles of Nominal Exchange Rate and Price Adjustment, April 2003

925 Ugo Trivellato and Anna Giraldo, Assessing the 'Choosiness' of Job Seekers. An Exploratory Approach and Evidence for Italy, April 2003

926 Rudi Dornbusch and Stanley Fischer, International Financial Crises, April 2003

927 David-Jan Jansen and Jakob de Haan, Statements of ECB Officials and their Effect on the Level and Volatility of the Euro-Dollar Exchange Rate, April 2003

928 Mario Jametti and Thomas von Ungern-Sternberg, Assessing the Efficiency of an Insurance Provider - A Measurement Error Approach, April 2003

929 Paolo M. Panteghini and Guttorm Schjelderup, Competing for Foreign Direct Investments: A Real Options Approach, April 2003

930 Ansgar Belke, Rainer Fehn, and Neil Foster, Does Venture Capital Investment Spur Employment Growth?, April 2003

931 Assar Lindbeck, Sten Nyberg, and Jörgen W. Weibull, Social Norms and Welfare State Dynamics, April 2003

932 Myrna Wooders and Ben Zissimos, Hotelling Tax Competition, April 2003

933 Torben M. Andersen, From Excess to Shortage - Recent Developments in the Danish Labour Market, April 2003

934 Paolo M. Panteghini and Carlo Scarpa, Irreversible Investments and Regulatory Risk, April 2003

935 Henrik Jacobsen Kleven and Claus Thustrup Kreiner, The Marginal Cost of Public Funds in OECD Countries. Hours of Work Versus Labor Force Participation, April 2003

936 Klaus Adam, George W. Evans, and Seppo Honkapohja, Are Stationary Hyperinflation Paths Learnable?, April 2003

937 Ulrich Hange, Education Policy and Mobility: Some Basic Results, May 2003 